\title{
Reflexões sobre a produção literária franciscana no século XIII
}

\author{
Andréia Cristina Lopes Frazão da Silva \\ Universidade Federal do Rio de Janeiro - CNPq
}

\section{Introdução}

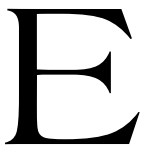

ste artigo tem como principais objetivos apresentar o quadro histórico geral do nascimento do franciscanismo e traçar reflexóes sobre a produção literária cuja autoria é atribuída a Francisco, bem como sobre os textos hagiográficos que lhe foram dedicados pelos frades no chamado primeiro século franciscano. Mais do que apresentar uma problemática e hipótese originais, desejamos elaborar um quadro sintético das relações entre a Península Itálica nos séculos XII e XIII, o nascente franciscanismo e a sua produção literária.

Nossa abordagem é histórica e visa colocar em diálogo contexto, autoria e texto, realçando as interconexões dinâmicas entre estes elementos. $\mathrm{O}$ termo contexto, segundo o Houaiss, ${ }^{1}$ deriva do verbo contexère, que significa entrelaçar, reunir tecendo. Este verbo já era usado, desde a antiguidade, para indicar a idéia de fazer ligação, dentre outros sentidos. Neste artigo, partindo desta idéia, adotaremos a definição de contexto como inter-relação de circunstâncias que se conectam aos personagens, em nosso caso, Francisco e seus primeiros biógrafos, e à produção textual.

A construção dos contextos históricos é uma das tarefas do historiador, que a partir do estudo dos múltiplos testemunhos do e sobre o passado, à luz de referenciais teóricos e metodológicos, visa recuperar acontecimentos, traçar interligaçôes entre eles e interpretá-los, elaborando sínteses. Desta forma, como em outros campos do conhecimento, o

${ }^{1}$ HOUAIS, 2009, CD-ROM. 
historiador produz saberes aproximadamente exatos sobre o passado, ${ }^{2}$ preocupando-se, inclusive, em realçar aspectos que sequer eram perceptíveis e/ ou valorizados pelos contemporâneos aos períodos estudados.

Faz-se importante destacar que os homens interagem uns com outros e com variadas instâncias da organização social. Elementos diversos, e até contraditórios, estão presentes em uma dada sociedade em um momento específico e incidem de formas diferentes nos personagens históricos e, por extensão, nos testemunhos produzidos pelos grupos. E sobre alguns aspectos do social, sequer foram preservados documentos. Assim, cabe ao estudioso inventariar, seja diretamente nas chamadas fontes ou em textos historiográficos, o maior número de dados, discutindo as possíveis conexôes que ligam os personagens e textos estudados às múltiplas instâncias do social.

No caso específico da produção literária, em nosso caso, os textos franciscanos produzidos no século XIII, éfundamental destacar que a relação texto-contexto dá-se nas diferentes etapas do processo comunicativo: na produção, na transmissão e na recepção. Assim, com o passar do tempo, não só os contextos sofrem alterações, mas também os textos, ao serem divulgados e apreendidos. Logo, o dinamismo do binômio contexto-texto não se estabelece somente no momento da composição textual, nem se limita à relação autor-contexto, mas também aos receptores e aos múltiplos processos de transmissão/interdição.

\section{A Península Itálica nos séculos XII e XIII}

Francisco de Assis nasceu ao final do século XII, "no coração do período do grande desenvolvimento do Ocidente medieval e em uma região fortemente marcada por este desenvolvimento", como destaca Le Goff. ${ }^{3}$

${ }^{2}$ Ou melhor, de parcelas do passado, já que é impossível captar tudo o que passou.

${ }^{3}$ LE GOFF, 2001, p. 23. 
Como a historiografia tem demonstrado, ${ }^{4}$ os séculos XII e XIII foram marcados por profundas transformações em diversos campos da organização social, ainda que com muitas variedades regionais.

No caso específico da Península Itálica, um elemento particular explica e fundamenta as transformaçōes: a forte presença da herança cultural romana na regiáo. Roma fora a capital do Império Romano e manteve-se como cidade imperial no medievo. Também era sede do bispado mais importante do Ocidente. Além disso, parcelas da península ficaram sob domínio bizantino até o século X. Assim, ainda que sofrendo desgastes ou reapropriaçōes, a estrutura urbana, as estradas, o uso do direito romano, a cristianização, dentre outros aspectos, foram preservados.

A Península Itálica foi, durante todo o medievo, uma área estratégica e central na geopolítica ocidental como espaço de encontro entre o Ocidente e o Oriente e o Norte e o Sul da Europa. No momento em que Francisco viveu, esta região estava dividida entre o Reino da Itália, submetido ao Imperador e divido entre senhores feudais, em sua maioria, bispos; os chamados Estados Papais, e o Reino da Sićlilia. Este último, com grande projeção mediterrânica e forte presença muçulmana, fora dominado pelos normandos desde fins do século XI e unido ao Império pelo casamento de Henrique VI e Constança da Sićlia, em fins do século XII.

A presença de dois poderes que lutavam pelo reconhecimento universal de sua autoridade, o imperial e o papal, propiciou, dentre outros fatores, a conquista de autonomia de diversas cidades italianas, documentadas desde o século X. Elas reconheciam a sua submissão simbólica e formal ao Imperador ou ao Papa, mas, na prática, elegiam magistrados, possuíam leis e tribunais próprios, cobravam impostos, cunhavam moedas, decretavam guerras, organizavam a defesa, etc.

${ }^{4} \mathrm{O}$ quadro contextual apresentado neste artigo é uma síntese da leitura de diversos trabalhos. A referência completa das obras que consideramos mais significativas sobre o período aqui estudado encontra-se na bibliografia final. Só incluiremos notas quando houver a apresentação de dados estatísticos ou transcriçôes de obras. 
Neste espaço, onde conviviam múltiplas instâncias de poder, os conflitos foram constantes, seja entre o Papa e o Imperador, destes contra as cidades, bem como entre elas ou internas, por razóes diversas: apoio ao Papado ou ao Império; ${ }^{5}$ disputas pelo controle de áreas de comércio; pela direção das cidades; entre os diversos grupos urbanos, entre as elites locais, etc.

Um dos principais indícios das transformações operadas nos séculos XII e XIII na Europa em geral foi, segundo os estudiosos, o crescimento demográfico, ainda que seja difícil precisá-lo. Como destaca Angel Barrios García, "la investigación en demografía histórica comporta varios riesgos, y si se refiere al periodo medieval no es el menor la carencia de fuentes" ${ }^{6}$ $\mathrm{O}$ autor acrescenta que no estudo da demografia medieval é preciso explorar diferentes fontes, já que os documentos demográficos, ou seja, os que têm a preocupação de contabilizar a população são praticamente inexistentes. Além disso, há que formular questões que permitam explorar os testemunhos disponíveis e, por fim, ler de forma crítica as fontes. ${ }^{7}$

Neste sentido, são apontados como testemunhos indiretos do crescimento demográfico, nos séculos XII e XIII, os movimentos migratórios e deslocamentos diversos das populaçôes por diferentes motivações; a ampliação das áreas cultivadas; o aumento dos preços das terras e do trigo; o crescimento da população urbana; o incremento do comércio e da produção manufatureira; a urbanização, e a construção de grandes prédios, como Templos.

Pautados nestes testemunhos, McEvedy e Jones afirmam que ao final do século XIII a densidade demográfica na Península Itálica chegou a 31 ou mais habitantes por $\mathrm{Km}^{2}$, o maior índice alcançado na Europa. Eles, porém, também afirmam que entre os séculos II ao XIII a região teve somente 60\% de aumento populacional, ou seja, cerca de metade da média geral de crescimento da Europa ocidental, que foi por volta de $120 \% .{ }^{8}$ Este dado

${ }^{5}$ Os que apoiavam o papado eram conhecidos como guelfos e os que eram partidários do imperador, gibelinos.

${ }^{6}$ BARRIOS GARCIA, 1984, p. 203.

${ }^{7}$ BARRIOS GARCIA, 1984, p. 204.

${ }^{8}$ McEVEDY E JONES, 1978, p. 23. 
permite concluir que, mesmo sofrendo com a baixa demográfica que marcou os séculos iniciais do medievo, esta península manteve-se como uma das áreas mais populosas do Ocidente, talvez, justamente, a presença dos legados romanos.

Como explicar este crescimento demográfico? Não há total consenso entre os autores sobre o que provocou este incremento populacional. Acreditamos, contudo, que a maior densidade demográfica resultou da combinação de diversos fatores, dentre os quais o fim das incursóes húngaras; as mudanças climáticas; o controle de epidemias; a maior oferta de alimentos; os pactos de Paz e Trégua de Deus, que buscaram limitar os conflitos entre nobres, e a diminuição da mortalidade, sobretudo a feminina.

A expansão populacional neste período vincula-se ao crescimento da riqueza em geral, tanto nas atividades que denominamos hoje como rurais quanto urbanas.9 Assim, foram introduzidas ou revitalizadas antigas técnicas agrícolas, como a rotação trienal ${ }^{10}$ e o uso de moinhos. Foram tornadas produtivas áreas como bosques e pântanos. Houve uma reorganização do espaço produtivo: o antigo sistema denominado dominical clássico - no qual as áreas eram divididas em reserva, terras do senhor e lotes dos camponeses - foi substituído pelo Senhorio, o que implicou na ampliação dos terrenos explorados pelos trabalhadores rurais em detrimento das demais áreas. ${ }^{11}$

Também surgiram múltiplas relações de trabalho, já que os lotes eram concedidos sob condições variadas, ampliou-se o número de

9 A principal forma de distinção dos espaços no medievo era o binômio povoado-ermo, ou seja, a divisão do espaço não era, como comumente hoje, entre áreas urbanas e rurais, mas entre as áreas ocupadas pelo homem e as ainda não exploradas. Cf. ZUNTHOR, 1994, p. 14-18.

${ }^{10}$ A rotação trienal era a alternância de períodos de pousio, com a plantação de cereais de verão ou legumes - como ervilhas, lentilhas, repolho, aveia - e de cereais de inverno, como trigo e centeio.

${ }^{11}$ Alguns fatores explicam esta mudança, tais como a necessidade de substituir taxas in natura por moeda e atrair camponeses para áreas de fronteira ou até então inexploradas. 
jornaleiros, ou seja, daqueles que recebiam por jornada de trabalho, bem como muitos acumulavam atividades pastoris com outras, como venda e produção de produtos manufaturados. Também foram introduzidos novos cultivos, ampliando a oferta de alimentos e plantas para fins manufatureiros, como as tintórias. Também consolidou-se a pecuária de transumância.

Os especialistas são unânimes em destacar que todos estes fatores propiciaram maiores rendimentos agrícolas, mas que estes ainda eram muito pequenos, se comparados aos atuais, e sujeitos a crises. Assim, se nos séculos iniciais do medievo, em média, para cada grão plantado colhiamse dois, nos séculos XII ao XIII este índice chegou a 4-5e, em locais muito produtivos, entre 6 a $8 .{ }^{12}$ Contudo, este aumento na produção não fez cessar períodos de fome, que foram registrados em vários momentos durante estes séculos: 1124-1125, 1139, 1145, 1197, 1233-1234. ${ }^{13}$

Nas cidades também houve progressos técnicos, sobretudo no constante às construçôes e produção de tecidos, o que implicou no crescimento das manufaturas. O comércio, tanto local quanto regional, e de longa distância, em especial no Mediterrâneo, expandiu-se tendo como protagonistas, sobretudo, genoveses e venezianos.

Ao incremento destas atividades vinculou-se a organização de confrarias de comerciantes e corporações de ofícios, bem como diversas relaçôes de trabalho. Houve ampliação da economia monetária, com o desenvolvimento do câmbio, e de incipientes atividades bancárias, como empréstimos, cheques, depósitos, transferências, etc.

Todas estas mudanças na produção influenciaram a organização social. Surgiram ou foram revitalizadas aldeias e cidades. Ainda que a maioria da população vivesse nas áreas rurais, foi perceptível a emigração rural e crescimento da população urbana, explicada, em parte, pelo empobrecimento de muitos camponeses devido à menor oferta de caça $\mathrm{e}$ coleta, resultado da redução das áreas de reserva e bosques, o que os deixava

\footnotetext{
${ }^{12}$ VÉRDON, 2006, p. 34.

${ }^{13}$ VÉRDON, 2006, p. 31.
} 
mais a mercê das colheitas. Outros ampliaram seus ganhos, acumulando as funçôes agrícolas com as comerciais nos mercados locais.

Outros fenômenos do período destacados pelos historiadores foram a afirmação da família nuclear; a fusão das "elites", ou seja, a união de famílias nobres e de ricos comerciantes, e a sistematização e consolidação de discursos de marginalização e/ou exclusão de diferentes grupos, como prostitutas; jograis; leprosos; homossexuais; hereges; judeus, e muçulmanos.

A expansão das escolas urbanas foi, também, um traço característico do período. Elas funcionavam nas catedrais e nas universidades. Nestes centros de saber enfatizava-se o estudo do latim, da prosódia, da retórica, do direito romano, da filosofia e da teologia. As aulas eram pautadas em leituras e debates, utilizando-se a razão para refletir sobre os livros sagrados e a tradição cristã. Ampliou-se a busca por saberes, já que havia interesse por conhecer o mundo natural. Assim, começaram a surgir reflexóes sobre o que hoje denominamos como ótica, química, fisiologia, farmacologia, etc.

Neste período foram realizadas muitas traduções, para o latim e para as línguas vernáculas que se consolidavam, de textos em grego e em árabe de temáticas diversas nas áreas de filosofia, medicina, astronomia, agronomia, matemática, etc. Também foram produzidas obras novas, com caráter douto ou voltadas para os iletrados. ${ }^{14}$

${ }^{14}$ Segundo Verger, na Idade Média Central só eram considerados letrados aqueles que dominavam a língua latina, ou seja, "as letras", daí o termo litteratus, então aplicado para referir-se aos homens cultos (1999, p. 27). O fato de uma pessoa ser chamada de iletrada não significa que ela era analfabeta. Como destacam vários autores, a educação básica medieval era similar em todo o Ocidente: geralmente junto às igrejas paroquiais, as crianças entre os 7 e 10 anos aprendiam a ler e a escrever em latim, bem como os fundamentos da gramática, a fim de capacitá-los para a pronúncia correta desta língua. Também estudavam canto e eram introduzidos aos cálculos matemáticos. Os livros de estudo continham fragmentos de textos latinos, orações e salmos e o método de ensino era calcado na repetição e memorização (Cf. Paul, 2003, p. 35-49). 
Com o surgimento das escolas urbanas ampliou-se o campo intelectual no Ocidente Medieval, pois estes centros de ensino vieram a somar-se aos outros já existentes - paroquiais, monásticos, citadinos - que ofereciam educação às pessoas, com conteúdos e em níveis variados. Neste sentido, podemos falar de uma multiplicidade educacional no medievo: pessoas com diferentes acessos à educação e, portanto, detendo conhecimentos distintos.

No tocante à religião, em diversas regiões da Europa e, em especial, na Península Itálica, surgiram vários movimentos. Vamos destacar os que consideramos mais significativos para a compreensão do contexto em que o franciscanismo surgiu.

Em primeiro lugar, sublinhamos as experiências eremíticas, que muitas vezes nasceram como experiências isoladas, de pessoas que buscavam a mortificação, a contemplação e a vida em pobreza, mas que acabavam por atrair seguidores, devido às atividades de pregação e assistência que realizavam, levando, em muitos casos, à formação de comunidades cenobíticas, como as Cartuxas. ${ }^{15}$

Em segundo, a chamada renovação monástica. A partir do fim do século XI, a vida monástica foi alvo de críticas, sobretudo no tocante à riqueza dos mosteiros e à ausência de atividades pastorais e de pregação. Assim, surgiram diversos movimentos, denominados reformadores, tais como os de Cister, Grandmont, Fontevrault e Premonté. Estes buscavam a retomada da regra de $\mathrm{S}$. Bento, fundamentando-se na austeridade e na simplicidade; priorizando a cura animarum e a pregação, e a busca de autonomia face aos poderes seculares locais. É nesse contexto que aparecem as ordens ou instituiçōes, grupos de mosteiros que seguem a mesma forma de vida, possuem uma identidade comum, e administração centralizada.

Nos séculos XII e XIII, a vida religiosa também foi ampliada com o surgimento de novas ordens. Ainda que realizando votos, seguindo uma

\footnotetext{
${ }^{15}$ Ordem religiosa fundada por Bruno no século XI que objetivava combinar os ideais eremíticos com os da vida cenobítica. O nome provém do local da primeira fundação, o Maciço Chartreuse, em português, Cartuxa.
} 
regra e vivendo comunitariamente, estes religiosos possuíam particularidades face aos monges. Organizaram-se três ordens distintas: a dos cônegos, homens ordenados que se dedicavam à pastoral, mas que também eram religiosos; a dos militares, que reuniam atividade militar e de assistência à vida regular, e a dos mendicantes, leigos ou ordenados que seguiam os ideais de pobreza pessoal e comunitária e dedicavam-se à pregação e à assistência dos marginalizados e/ou excluídos. Estas ordens foram reconhecidas pela Igreja e diversas instituiçóes vincularam-se a cada uma delas. ${ }^{16}$

E o clero secular? Os clérigos foram alvo de diversas normativas que objetivavam sua superioridade moral e autonomia face aos leigos; sua educação; o fortalecimento de sua autoridade, e sua atividade pastoral.

As transformações no campo religioso estavam intimamente relacionadas à institucionalização da Igreja, sob a liderança papal, nos séculos XI ao XIII, o que redundou em uma nova relação com os eclesiásticos, regulares e seculares, e os leigos. $\mathrm{O}$ papado, mesmo sem ter um plano previamente definido, com avanços e recuos, e em diálogo constante com as diversas instâncias de poder e segmentos sociais do período, desde o século XI, lançou mão de algumas estratégias que fortalecessem o seu poder e garantissem o seu reconhecimento como cabeça da Igreja. Nesse sentido, lutou-se contra a ingerência leiga; ampliou-se e reestruturou-se o Direito Canônico; desenvolveu-se ampla atividade legislativa, através de decretais, breves, bulas e etc.; passou-se a convocar concílios universais e a divulgar os decretos conciliares nas diversas províncias eclesiásticas; fundaram-se cortes eclesiásticas; instituiu-se que a eleição dos papas ocorreria através do Colégio de Cardeais; estabeleceu-se que caberia à Cúria a confirmação dos arcebispos eleitos; reorganizaram-se as redes paroquial e diocesana; os bispos foram dotados de maiores poderes; as comunidades de religiosos, salvo em caso de privilégio, foram submetidas ao episcopado; enviou-se legados como representantes diretos do papa para resolver conflitos locais e introduzir as normativas eclesiásticas em diversas regiōes; preocupou-se com

${ }^{16}$ Os franciscanos e dominicanos, por exemplo, eram instituições religiosas da ordem mendicante. 
a educação dos clérigos e leigos; buscou-se impor o uso da liturgia romana para toda cristandade ocidental; normatizou-se o casamento leigo e estabeleceuse a continência e/ou o celibato para os clérigos; organizaram-se os processos de canonização; difundiu-se a obrigatoriedade da confissão e a comunhão anual; estimulou-se a organização de Cruzadas contra os considerados infiéis e os hereges; organizou-se a Inquisição, dentre outras iniciativas.

Desta forma, não só o governo eclesiástico foi estabelecido, com a criação de vários organismos e instâncias de poder, como também se buscou implantar um modelo de sociedade na qual todos deveriam ter espaços e papéis bem definidos.

Sob a influência eclesiástica, mas atingindo muito mais do que os homens e mulheres da Igreja, os autores sublinham que foi delineado, no período em estudo, um novo ideal de religiosidade: a vida apostólica, que tinha como pontos principais a retomada dos ensinamentos do evangelho; a valorização dos leigos e da vida no século; a forma de vida comunitária; a pregação, e a pobreza. Este ideal, sem dúvida, influenciou os movimentos eclesiásticos acima apresentados, como o eremitismo e as novas ordens religiosas, mas também leigos.

Nos documentos há referências a movimentos penitentes. Até o século XII, estes não possuíam unidade. O elemento comum era a demonstração externa do arrependimento, que, no período de Francisco, era manifestado pelo uso de túnica, bastão, alforje e sandálias; o cuidado dos doentes; o auxílio na reconstrução de Igrejas; no fato de não portarem armas, absterem-se de andar a cavalo e participar de banquetes, etc. Estes movimentos, segundo os especialistas, foram institucionalizados no século XIII, com a formação de confrarias de penitentes e, posteriormente, incorporados aos mendicantes como Ordem Secular.

Também há a notícia de comunidades de leigos para ajuda aos leprosos; da organização de confrarias para celebração de festas, assistência e ajuda mútua, bem como de leigos que se colocavam sob a sua proteção e viviam em mosteiros, mesmo sem fazer os votos.

Dentre os diversos movimentos que se formaram desvinculados da Igreja há que destacar os que foram considerados como heréticos. Sobretudo 
a partir do século XII, por razões disciplinares ou teológicas, surgiram diferentes grupos que tinham em comum o questionamento da autoridade ou sacramentos da Igreja Romana, que foram combatidos com a pregação, os tribunais inquisitoriais e até uma Cruzada. É difícil estudar os movimentos que foram condenados heréticos, pois a documentação preservada é mínima e grande parte dos testemunhos é de origem eclesiástica. Dentre os declarados heréticos pela Igreja, encontravam-se os Cátaros, Valdenses e Umiliati. ${ }^{17}$

Os Cátaros ou Albigenses formavam um movimento com caráter anti-sacerdotal e anti-sacramental, que rechaçava o uso do latim litúrgico e do juramento, estimulando o ascetismo rigoroso e o contato pessoal com Deus. Propagavam uma teologia dualista, ainda que com divergências interpretativas internas, segundo a qual o deus bom e o deus mau estavam em constante luta. Os fiéis eram divididos em Perfeitos e Simples. Chegaram a constituir uma organização eclesial própria, como uma hierarquia formada por bispos. Difundiram-se, entre outras regiōes, pelo norte da Península Itálica. O grande sucesso dos Cátaros levou à organização de uma Cruzada para combatê-los, que se iniciou em 1209.

Os Valdenses, também conhecidos como Pobres de Lyon, surgiram por volta de 1176, com as pregaçóes de Pedro Valdo. Dedicaram-se à pregação itinerante, abraçaram os ideais de pobreza, e traduziram textos da Bíblia. Tiveram presença significativa na Lombardia.

Os Umiliati ou Humilhados, sobre os quais há muitas divergências devido às origens e as reivindicações semelhantes aos dos valdenses e arnaldistas, surgiram em Milão. Seus membros provinham dos segmentos mais pobres das cidades. Trabalhavam produzindo tecidos de lã baratos;

${ }_{17}$ Muitos outros grupos ou pessoas foram condenados pela Igreja neste período como heréticos, tais como Arnaldo de Brescia, líder da comuna em Roma, movimento que ocorreu entre 1147 e 1155; o abade cisterciense Joaquim de Fiori, cujos escritos foram reprovados no IV Concílio de Latrão e, posteriormente, influenciaram diretamente os espirituais Franciscanos; os patarinos, movimento anticlerical desenvolvido em Milão, dentre outros. 
praticavam o jejum; viviam em comunidades, com propriedade comum; dedicavam-se à pregação; negavam os juramentos e contestavam a Igreja.

Vale destacar que a política da Igreja diante de tais movimentos variou e alguns segmentos foram reconduzidos à ortodoxia, como os seguidores de Durando de Huesca, uma facção dos Valdenses, e os Umiliati, que foram organizados como uma ordem mendicante.

O sucesso dos movimentos considerados heréticos, a despeito das estratégias de combate desenvolvidas pela Igreja, pode ser explicado pelo uso das línguas vernáculas nas pregaçôes e liturgias; nos sermões simples, que exortavam à penitência, sem preocupaçōes teológicas; na acolhida e prestígio dados aos mais pobres, aos iletrados eàs mulheres, e na solidariedade dos grupos.

De que forma este contexto se liga a Francisco de Assis? Como ele e seus seguidores foram influenciados e influenciaram tal contexto? Como o apreenderam em seus escritos? Vamos tratar a seguir destas questões. Partiremos dos dados presentes nos testemunhos preservados, bem como nos estudos dos especialistas. ${ }^{18}$

\section{Francisco de Assis: reflexões sobre a sua biografia}

João, nome de batismo de Francisco, nasceu por volta de 1182, na cidade de Assis, localizada na Úmbria, região central da Península Itálica. Seu pai, Pedro Bernadone, era um rico mercador de tecidos que não pertencia a uma família nobre. Sobre a sua mãe há controvérsias, mas a maioria dos autores considera que era original da Provença.

Quanto à origem do nome Francisco há divergências. Segundo a Legenda dos Três Companheiros (LTC) 2, 1, ${ }^{19}$ "Francisco foi chamado

\footnotetext{
${ }^{18}$ Como o que apresentamos aqui é uma síntese elaborada a partir da leitura e interpretação de diferentes textos, optamos por apresentar as referências que foram consultadas na bibliografia final.

${ }^{19}$ Utilizaremos, para indicar as referências das fontes franciscanas, a forma de citação universal. A primeira vez que uma fonte for mencionada, citaremos o título seguido da abreviatura, que será adotada a seguir. As fontes
} 
primeiro de João, pela mãe; mas depois foi chamado de Francisco pelo pai, que estava voltando, então, da França, e em cuja ausência ele tinha nascido”. Outra explicação está no fato do Poverello ter sido um admirador do trovadorismo francês e, em alguns momentos expressar-se nesta língua. Daí o apelido Francisco, ou seja, algo como "francesinho". ${ }^{20}$

Francisco, como o pai, atuou como comerciante. Para tanto, obteve uma educação básica. Segundo a $1 \mathrm{Cel} 23$, o assisense "começou a pregar onde em criança aprendera a ler", sintetizando a formação educacional de Francisco. Ele estudou, provavelmente, em uma escola paroquial, onde aprendeu a ler, a escrever e a calcular, conhecimentos fundamentais para exercer seu ofício. ${ }^{21}$ Além desta educação formal, Francisco adquiriu conhecimentos práticos ao exercer sua atividade comercial e viajar por diversas cidades, e não só da Península Itálica.

Francisco vivia em uma cidade e, portanto, conviveu, no seu dia a dia, com diversos aspectos das transformaçôes que marcaram o período. Dentre estes, destacamos o aumento da população citadina; a construção de grandes prédios; a proliferação de movimentos religiosos leigos, como a organização de confrarias e de associações de penitentes; a perseguição às heresias, etc. E, certamente, teve contato com letrados, clérigos, pobres, leprosos, jograis e prostitutas nas ruas da cidade.

Francisco também sofreu diretamente o impacto dos conflitos entre as diferentes instâncias de poder na Península Itálica. Em 1200, quando tinha cerca de 18 anos, provavelmente participou da revolta dos citadinos que resultou na organização da comuna de Assis. Neste momento, os

franciscanas que são apresentadas neste artigo encontram-se disponíveis on line, em edição bilíngüe português-latim coordenada pelo Frei José Carlos Pedroso, em www.procasp.org.br. Acesso em 31/01/2010. Quando as fontes não estão disponíveis neste site, remitiremos a outros.

${ }^{20}$ Vida I de Tomás de Celano (1 Cel) 16, 1; Vida II de Tomás de Celano (2 Cel) 13, 127; e LTC 2,3; 10,6; 23,8; 24,4-5; 33,2.

${ }^{21}$ Sobre a educação dos mercadores no medievo ver CAUNEDO DEL POTRO, 2006. 
nobres se refugiaram nas cidades vizinhas, retornando após o tratado de paz assinado entre os bons homens e os homens do povo em $1203 .{ }^{22} \mathrm{Em}$ 1202, lutou na guerra entre Assis e Perúgia. Assis saiu perdedora e o Assisense ficou prisioneiro em Perúgia durante um ano. Em 1204, preparou-se para participar de uma guerra, junto ao exército papal liderado por Gualtério de Brienne, na Apúlia, região sob o domínio do Imperador, mas desistiu a caminho da região, voltando para sua cidade.

Foi a partir deste momento, provavelmente sensível aos efeitos das mudanças sociais e econômicas e das situaçôes de conflito nas quais participou, que Francisco iniciou, segundo os documentos, uma mudança de comportamento que culminou com o rompimento com o seu ofício de mercador e a adoção da vida de penitente. Assim, começou a restaurar templos, dar esmolas, praticar o jejum e dedicar-se à oração em locais retirados, até que finalmente rompeu com a família, por volta de 1206, e passou a viver na Igreja de São Damião.

Alguns anos depois, em 1208, iniciou sua atividade de pregação, que exortava à penitência. A partir deste momento começou a atrair seguidores. Provavelmente por mediação do bispo de Assis, em 1209, Francisco e seu grupo foram a Roma solicitar ao então papa Inocêncio III aprovação para o seu modo de vida religioso. Acredita-se, que neste momento, já havia uma regra primitiva, que foi aprovada oralmente pelo pontífice. Iniciou-se, desta forma, a institucionalização do movimento, que se organizou como uma ordem mendicante.

O primeiro grupo de frades estabeleceu-se em Porciúncula, empréstimo de monges cluniascenses. A partir deste local, realizavam viagens missionárias, inclusive entre os infiéis. $\mathrm{O}$ próprio Francisco esteve em Damieta durante a quinta cruzada, pregando para o Sultão, e, posteriormente, em São João de Acre.

${ }^{22} \mathrm{O}$ texto deste tratado está disponível em espanhol em www.franciscanos.net/ document/tratado1.htm. Acesso em 06/02/2010. Segundo os documentos, houve, em 1210, outra revolta e um novo tratado de paz foi feito. Neste, assinam os Maiores e Menores da cidade de Assis. 
A fraternidade cresceu e se expandiu. Eremitérios e conventos foram fundados em diversas regiões da Europa. Foram recebidas mulheres, que se organizaram em comunidades específicas. A fama dos ideais franciscanos atraiu os letrados e foram criadas escolas para preparar os frades para a pregação. Os frades, seguindo as diretrizes romanas, realizavam capítulos anuais, ou seja, reuniōes gerais para decidir os rumos do grupo. Ao longo do século XIII foram assumindo postos na hierarquia clerical, como bispos, arcebispos, cardeais e até papas; atuaram em açôes diplomáticas; no combate aos hereges, como capelães nas cruzadas, como professores nas universidades, etc.

Com a expansão da ordem, tanto numérica quanto social e geograficamente, problemas e divergências começaram a surgir. Assim, já em 1220, Francisco renunciou à direção da fraternidade. Contudo, trabalhou na revisão da regra primitiva. Uma primeira proposta foi apresentada no capítulo de 1221, que foi discutida e corrigida. O texto final foi aprovado pelo papa Honório III em 1223 e é conhecido como Regra Bulada. ${ }^{23}$

Nos seus dois últimos anos de vida, Francisco dedicou-se à meditação, e à oração, fazendo ainda viagens de pregação. Estava já muito doente, chegando a fazer alguns tratamentos médicos, como uma cauterização nos olhos. Ele faleceu em 1226, em Assis.

Dois anos após a sua morte, Francisco foi canonizado pelo papa Gregório IX após um processo, como era então a normativa papal. Seu culto foi difundido paulatinamente e a fim de registrar e propagar a sua memória, várias hagiografias lhe foram dedicadas. Após o seu falecimento, a fraternidade continuou a crescer, adaptando os ideais do fundador às novas demandas do grupo e às diretrizes de Roma. Este crescimento influenciou diretamente a produção hagiográfica sobre Francisco pelos frades e, por extensão, a formação de memórias sobre a trajetória e ensinos do santo durante o século XIII.

${ }^{23} \mathrm{O}$ texto desta Regra com a aprovação e assinatura papal conserva-se atualmente no Sacro Colégio de Assis. 


\section{Textos do primeiro século franciscano: algumas considerações iniciais}

Um conjunto de variáveis é fundamental para a compreensão dos escritos do primeiro século franciscano. Em primeiro lugar, o caráter escrito/ oral da sociedade medieval. Como nesta sociedade, o escrito não era o meio hegemônico para transmissão de idéias, suas funções eram distintas das ocupadas hoje. Neste sentido, escrevia-se para marcar um dado posicionamento; consolidar uma dada memória ou para fundamentar uma antiga tradição. Ou seja, o escrito visava, sobretudo, resguardar uma verdade para posteridade, mais do que servir de instrumento de comunicação no presente.

A transmissão é um aspecto que não deve ser ignorado. No caso específico dos textos em estudo, há que pensar em transmissão tanto oral quanto escrita. Transmissão oral porque muito do que é atribuído à autoria de Francisco ou informações sobre sua biografia foram, primeiramente, proferidos oralmente e só em um segundo momento foram registrados. Quanto à transmissão escrita, há que lembrar que os textos eram perpetuados por manuscritos que muitas vezes sofriam mudanças devido a problemas ao serem copiados, erros de encadernação, desgastes com o passar do tempo ou porque sofreram grandes avarias devido a incêndios, inundações, mofo, etc. ou, deliberadamente, parou-se de copiá-los.

Outro elemento a ser sublinhado é o caráter de oficialidade dado a alguns destes escritos em detrimento de outros. Com a expansão e institucionalização da ordem foi necessário rever e eleger uma memória oficial sobre os feitos e lições de Francisco. Neste sentido, os seus escritos foram hierarquizados e algumas das hagiografias escritas sobre ele proibidas de circular.

Por fim, há que realçar a variedade formal, os objetivos diversos e os públicos distintos para os quais tais escritos foram elaborados. Dividimos estes textos em dois grupos: os escritos atribuídos a Francisco e os escritos sobre o Poverello elaborados pelos frades no século XIII.

Há que destacar que os frades produziram outros textos neste período, mas que não tiveram como temática a biografia do Assisense, 
como a Crônica de Frei Salimbene de Adam ou os Sermões de Antônio de Lisboa /Pádua. Também há diversas mençôes a Francisco e seus seguidores em várias obras compostas neste mesmo século, mas cujos autores não eram frades. Como o Franciscanismo tornou-se uma instituição eclesiástica, diversos documentos papais mencionam o santo ou tratam de questóes relacionadas à Ordem. Estes materiais não serão abordados neste artigo.

\section{Os escritos atribuídos a Francisco}

Como já assinalamos, Francisco era alfabetizado. Contudo, não era um douto, ou seja, não freqüentou uma escola episcopal ou foi à universidade para estudar retórica, filosofia, direito ou teologia. Provavelmente conhecia os rudimentos do latim e é possível que, mesmo sem ler ou escrever nesta língua, era capaz de compreendê-la quando falada e/ou escrita. Porém, teve problemas nos olhos, o que certamente comprometeu a sua visão e sua habilidade de enxergar e, portanto, de redigir. Logo, se há um grande conjunto de materiais atribuídos a Francisco, ${ }^{24}$ poucos, porém, foram escritos de seu próprio punho, como o foi o Bilhete para Frei Leão.

Dentre os considerados como escritos de Francisco encontram-se os que foram redigidos por secretários, mas ditados pelo Poverello, como o Testamento. Como tais textos apresentam estilos diferentes, sofreram, incontestavelmente, a interferência dos redatores. Alguns, como as Admoestaçôes, foram, provavelmente, primeiramente proferidos como pregação ou ensinamento aos frades e só posteriormente alguém os registrou. Há textos que lhe são atribuídos por terceiros, como a Forma de Vida para Santa Clara, que é citada pela religiosa no capítulo VI de sua Forma de Vida. ${ }^{25}$ Também são considerados escritos de Francisco os que foram de autoria coletiva, como a Regra Bulada.

\footnotetext{
${ }^{24}$ A listagem completa dos textos atribuídos a Francisco e a edição em latimportuguês, como já destacado na nota 19, encontram-se em www.procasp.org.br. ${ }^{25}$ Os escritos clarianos também encontram-se disponíveis em www.procasp.org.br.
} 
É provável que alguns escritos de Francisco estejam ainda perdidos. O último encontrado que lhe foi atribuído foi publicado pela primeira vez em 1977, Canto di esortazione di San Francesco per le poverelle di san Damiano. Também conhecido como Ouvi, pobrezinhas ou Audite Poverelle, trata-se de um cântico feito para as irmãs de São Damião.

Há cerca de 197 manuscritos conhecidos com materiais atribuídos à autoria, direta ou indireta, de Francisco. ${ }^{26}$ Contudo, como destaca Dalarun, ainda falta um rigoroso estudo crítico deste material que "través del léxico, el estilo, la cualidad del lenguaje, el uso del cursus, poder distinguir mejor lo que en sus escritos es realmente próprio de Francisco" ${ }^{27}$

Dentre os escritos de Francisco há textos de caráter litúrgico, como hinos, orações, ofícios; pequenos bilhetes; bençãos; admoestações; regras; cartas, e testamentos. Eles foram transmitidos em sua grande maioria em latim, mas há alguns materiais preservados no dialeto umbro, como o Cântico de Frei Sol. O valor e o uso dados a esses documentos, no decorrer do tempo e por variados grupos, foi bem diverso, o que, em nossa opiniāo, significou uma "hierarquização dos escritos", que se vincula aos conflitos internos da ordem, às práticas da religiosidade, à intervenção papal, etc. Vejamos alguns exemplos.

A já citada Benção a Frei Leão, um autógrafo de Francisco, é considerada como relíquia. Escrita em pergaminho, é mantida em um relicário, na basílica de Assis, desde o Medievo. No Testamento, ditado pelo Assisense um pouco antes de falecer, é pedido que o mesmo fosse lido junto à regra - "E tenham sempre este escrito consigo junto da Regra". Ou seja, o Poverello dotou este texto com igual valor ao da Regra aprovada pelo Papa. Contudo, logo após a sua morte, discutiu-se a validade deste documento. Em 1230, na bula Quo elongati, Gregório IX declarou que a leitura e a observância do Testamento não era obrigatória. ${ }^{28} \mathrm{O}$ texto

\footnotetext{
${ }^{26}$ DALARUN, 1998, p. 48.

${ }^{27}$ DALARUN, 1998, p. 49.

${ }^{28} \mathrm{O}$ texto completo desta bula em português está disponível em http:// www.vocacoes.com.br/l_ estudosbula.htm. Acesso em 08/02/2010.
} 
conhecido como Última Vontade para Santa Clara, como o anteriormente citado, só é conhecido através do capítulo VI da Forma de Vida, de autoria da primeira franciscana. Trata-se de uma exortação à vida em pobreza que, certamente, foi incorporada por Clara para dar legitimidade e autoridade aos seus próprios escritos.

Os textos atribuídos a Francisco apresentam muitos problemas relacionados à autenticidade, transmissão, valor e uso. Contudo, são testemunhos imprescindíveis para a construção de saberes sobre as primeiras décadas do franciscanismo, tais como os ensinos do fundador e a forma como foram apreendidos. Também podem ser considerados monumentos lingüísticos, sobretudo no tocante ao dialeto umbro, bem como exemplares da produção escrita não douta do período.

\section{Escritos dos frades sobre Francisco do século XIII}

Dentre o conjunto de obras produzidas pelos frades no século XIII, algumas têm como tema a vida e/os feitos e/ou os ensinos de Francisco. Passamos a apresentá-las brevemente:

A Epistola Encyclica de Transitu S. Francisci (El), também conhecida como Carta de Frei Elias, é datada de outubro de $1226 .{ }^{29}$ Esta epístola, redigida pelo então Vigário Geral da Ordem, comunica a morte de Francisco a todos os irmãos, mencionando os estigmas. Elias, seu autor, foi um dos primeiros seguidores de Francisco. Ele foi vigário geral em 1221, e, posteriormente, Ministro Geral entre 1232 e 1239, quando foi deposto, em meio a conflitos no interior da Ordem. Era um irmão leigo que apesar de escrever em latim, não era um douto.

O Sacrum commercium beati Francici cum domina Paupertate (Al), ou Aliança Sagrada, foi redigido em $1227 .{ }^{30}$ A autoria desta obra ainda é

${ }^{29}$ Disponível em http://www.editorialfranciscana.org/files/_Carta_de_Frei_Elias_ (CE)_4af84f 866d3fd.pdf. Acesso em 08/02/2010.

30 José Carlos Pedroso defende em sua edição on line que deve ter sido escrita entre 1260 e 1270. 
tema de discussão. $\mathrm{O}$ texto tem caráter alegórico, apresentando uma visão teológica sobre a pobreza. Nele, Francisco e alguns frades buscam a Pobreza, personificada como uma Dama. Após encontrarem-na, inicia-se um diálogo, durante o qual ela narra a sua trajetória desde a criação do mundo. O relato termina com um banquete para o qual a Pobreza foi convidada por Francisco e seus companheiros.

São da autoria de Tomás de Celano quatro obras sobre o Santo. Ele foi o primeiro hagiógrafo de Francisco, escolhido pelo próprio papa. Como não era o único letrado franciscano na época, sua eleição, certamente, baseou-se em critérios além de suas habilidades intelectuais.

Como as suas obras revelam fidelidade aos textos hagiográficos altomedievais, conhecimentos de latim e retórica, e de autores patrísticos, é provável que tenha estudado em um ambiente monástico. Uniu-se ao grupo de seguidores de Francisco em 1215. Foi custódio e, depois, ministro regional de Worms, Moguncia, Espira e Colônia. É provável que tenha trabalhado como copista na biblioteca do Sacro Convento em Assis. No fim da vida, deu assistência espiritual às clarissas de São João de Varri, na Marca de Ancona, onde, segundo a tradição, morreu em 1260.

A Primeira Vida (1Cel) foi aprovada pelo papa em 1229 . O objetivo desta obra era apresentar para toda cristandade a biografia e os milagres do santo recém canonizado. A Segunda Vida (2Cel) foi redigida por volta de 1244 a 1247, por solicitação do então Ministro Geral da Ordem, Crescêncio de Iesi. Esta hagiografia complementa a anterior e apresenta o Poverello como modelo a ser seguido, sobretudo pelos frades.

É importante destacar que no capítulo de 1244 foi solicitado a todos os irmãos que enviassem informações sobre São Francisco para o Ministro geral, com o objetivo de que uma nova Vida fosse composta. É provável que este material, ao menos em parte, tenha sido entregue a Celano para compor este livro.

A Legenda ad usum chori (4Cel) é um resumo da vida do Assisense para fins litúrgicos. Não há consenso sobre sua datação. Alguns apontam o ano de 1230 e outros 1250. O Tratado dos Milagres (3Cel), redigido provavelmente entre 1250-1253, realça a santidade de Francisco narrando diversos feitos maravilhosos que lhe foram atribuídos. 
A Legenda da Úmbria (LU), ${ }^{31}$ que também já foi chamada de Legenda Napolitana, é uma obra pouco conhecida, pois não foi incluída na maioria das ediçōes das fontes franciscanas, salvo a americana, de 2000. Esta obra foi alvo de diversos debates. Segundo o maior estudioso da LU na atualidade, Dalarun, este texto foi composto entre 1229 e 1232 no Sacro Convento de Assis. Devido às características estilísticas, Tomás de Celano pode ter sido o seu autor. Esta obra é favorável a Elias, que talvez tenha sido o seu promotor. E provavelmente por isto teve pouca circulação, já que o Ministro Geral foi deposto, como assinalamos.

A Vida de São Francisco (Jul) e o Officium Sancti Francisci (JuOf), também conhecido como Officium ritmicum, foram compostas por Juliano de Espira, sobre o qual pouco se sabe. Ele provavelmente foi mestre de canto da corte dos reis de França. Por volta de 1227 já ingressara na Ordem, atuando na região de Colônia e Worms. Foi também mestre de canto na Escola Teológica de Magdeburgo. Morreu por volta de 1250.32

Jul foi escrita entre 1232 e 1235. Narra, de forma breve e douta, a biografia, a morte e a canonização do santo, segundo os especialistas, de forma muito dependente da $1 \mathrm{Cel}$, mas acrescentando dados sobre a trasladação dos restos mortais de Francisco. A JuOf são hinos para serem cantados na festa de celebração do santo de Assis.

A Legenda Maior (LM) e a Legenda Menor (Lm) são de autoria de Boaventura, letrado que estudou e foi professor da Universidade de Paris, cuja produção bibliográfica é extensa. Ingressou na Ordem em 1243, chegando a Ministro Geral em 1257. Em 1273, foi nomeado bispo de Albano e cardeal. Faleceu logo depois, em 1274.

A LM apresenta a trajetória de Francisco organizada por temas. Nela abundam os recursos retóricos, como o simbolismo numérico, e as reflexōes teológicas. A Lm é um resumo desta obra, realizada com fins litúrgicos. A

${ }^{31}$ Disponível em http://www.editorialfranciscana.org/files/5707_4_Legenda_ da_Umbria_(LU)_4af8505b5bfe3.pdf. Acesso em 10/02/2010.

${ }^{32}$ Para alguns autores, ele morreu entre 1275 a 1285. 
LM foi apresentada ao capítulo geral de 1262 . Em 1266, esta hagiografia foi declarada a única oficial sobre Francisco e foi ordenado que todas as demais fossem destruídas.

O Liber de Laudibus (LL), ou Livro dos Louvores de São Francisco, foi escrito por Bernardo de Bessa. Há poucos dados conhecidos sobre este autor, salvo que provavelmente era oriundo do sudoeste da atual França e que era próximo de Boaventura. A obra, dividida em nove capítulos, apresenta de forma sintética a biografia e o legado do Assisense. Foi composta após a LM.

O Anônimo Perusino (AP) narra a trajetória de Francisco e o início da fraternidade. Há diversas discussōes sobre a sua autoria. Como uma das principais hipóteses defende que esta obra contém as tradiçōes transmitidas por Frei Egídio, é proposto como autor um de seus discípulos, frei João de Perúgia. Várias datas são apontadas como as prováveis de composição: 1240-1241; entre 1266 e 1270, e pós 1290.

A Legenda dos Três Companheiros (LTC) é uma obra anônima sobre a qual há muitos debates. Ela recebeu esse título porque os manuscritos que a transmitem iniciam-se com uma carta, dirigida ao Ministro Geral, datada de 11 de agosto de 1246, assinada por Frei Leão, Frei Rufino e Frei Ângelo, uns dos primeiros companheiros de Francisco.

A crítica mais moderna acredita que esta epístola, ainda que autêntica, foi incluída posteriormente à obra. Provavelmente esta hagiografia foi escrita em Assis, por um frade ligado ao Sacro Convento com a formação de notário e acesso à biblioteca. É possível que ele tenha coletado e registrado as tradições do primeiro grupo de seguidores de Francisco. Quanto à datação, estudos mais recentes apontam os anos de 1244 e 1246 para a redação dos 16 primeiros capítulos e após 1266 para os dois últimos.

O Speculum Perfectionis (minus) (1EP), ${ }^{33}$ também conhecido Espelho da Perfeição menor ou Speculum de Lehmens, devido ao nome do

33 Vale destacar que esta obra não deve ser confundida com o Espelho de Perfeição, datada de 1318. 
pesquisador que encontrou o manuscrito contendo a obra, reúne episódios da vida de Francisco provenientes de várias fontes, inclusive orais, sublinhando, dentre elas, os escritos de Frei Leão. A redação é datada após 1266, já que o texto se apresenta como uma espécie de versão alternativa para a LM. Durante muito tempo foi considerada um rascunho do Espelho da perfeição (EP), sendo excluído, como LU, da grande maioria de edições das fontes franciscanas.

Como é possível verificar, os textos produzidos sobre Francisco pelos frades no século XIII apresentam múltiplas diferenças. Em primeiro lugar, devido à formação intelectual dos autores, que detinham diversos saberes. Se entre eles havia um doutor de Paris, havia também um notário, um mestre de canto e um frade com formação monástica tradicional. Além disso, havia diferenças quanto à motivação pela qual os textos foram compostos. Vejamos alguns exemplos.

El, escrita ao sabor dos acontecimentos, tinha como meta informar sobre a morte do fundador e alçá-lo à categoria de santo ao informar sobre os estigmas:

apraz-me comunicar-vos uma notícia muito alegre, um autêntico milagre, um prodígio que nunca acontecera a não ser no Filho de Deus, Cristo Senhor. É que, não muito tempo antes da morte, também o nosso Irmão e nosso Pai foi como que crucificado, trazendo impressas no corpo cinco feridas, indubitavelmente as cinco chagas de Cristo.

Já a 1 Cel, como já destacamos, tinha o objetivo de consolidar a memória e o culto do santo que fora recentemente canonizado. Para tanto, o autor reafirma a idéia de santidade circulante na Península Itálica, no século XIIII, e demonstra que Francisco era digno de ser contado entre os santos. Desta forma, a obra incorpora topoi comuns aos textos hagiográficos medievais: lista as virtudes espirituais do santo (1 Cel 83); menciona o seu desejo pelo martírio (1 Cel 55); retrata-o como um miles Christi em batalha contra o mal (1 Cel 72); narra seus atos milagrosos (1 Cel 63, 65, 67, 68, 69); sublinha o seu relacionamento misericordioso com os pobres e doentes (1 Cel 17, 76), etc. 
Quanto ao autor do 1EP, estava preocupado em registrar uma memória de Francisco que se opunha à oficial. Na obra lemos:

Em nome do Senhor começa o Espelho da perfeição, da regra e da profissão, da vida e da vocação do verdadeiro frade menor, segundo a vontade de Cristo e a intenção do bem-aventurado Francisco, composto de algumas descobertas nos escritos do santo Frei Leão, companheiro do bem-aventurado Francisco, e de outros companheiros dele, que não estão na Legenda comum. Neste espelho reluz também, de alguma forma, a perfeição da vida do bem-aventurado Francisco.

A Legenda Comum em questão é a LM, a biografia oficial eleita pelo capítulo de 1266.

Também diferenciavam quanto ao público-alvo que buscavam atingir: em alguns casos, toda a cristandade, como os ofícios litúrgicos, que foram compostos por Juliano de Espira e Tomás de Celano, para a celebração da festa de São Francisco. Em outros, somente os frades, como a 2 Cel. Este livro, composto 20 anos depois de $1 \mathrm{Cel}$, em um momento em que a Ordem vivia problemas internos, a $2 \mathrm{Cel}$ se dirige aos frades, de forma didática, denunciando certos comportamentos que considerava contrários aos ideais do fundador.

Por fim, quanto à forma. Entre as obras há uma carta, ofícios litúrgicos e narrativas diversas. Apesar de todos estarem redigidos em latim, devido à formação de seus autores, apresentam recursos retóricos diversos. Em alguns abundam as referências a textos bíblicos, patrísticos e obras teológicas. Alguns são breves e outros mais extensos. Uns apresentam a vida do santo seguindo a cronologia, enquanto outros por temas, ou só reúnem episódios.

Estes escritos também elaboram distintas memórias sobre o fundador. Com o crescimento e a institucionalização do movimento, surgiram conflitos, internos e externos, e múltiplas questóes foram levantadas. Ao se remeterem a Francisco e seus ensinamentos, diferentes respostas eram encontradas. Como assinalamos na introdução, a apreensão e perpetuação dos textos é um processo dinâmico e só parcialmente afetado pela autoria. 
Estas obras também suscitam muitos problemas acadêmicos. Como assinalamos, ainda há muitas divergências quanto à autoria, autenticidade, transmissão manuscrita e datação de muitas destas obras. Por exemplo, a autoria da $\mathrm{Al}$ foi atribuída a vários frades, tais como João Parenti, que foi ministro geral da Ordem entre 1227 a 1231; Antônio de Lisboa/ Pádua; Crescêncio de Iesi, ministro geral de 1244 a 1247; João de Peckam, frade que foi arcebispo de Canterbury, etc. Também discutese a transmissão de El. A primeira edição desta carta data de 1620, a partir de um manuscrito achado no convento dos Recolletti de Valenciennes. Este perdeu-se e nenhuma outra cópia foi encontrada. Foram levantadas dúvidas sobre a autenticidade do texto, mas parece ser consenso entre os autores de que o material da qual atualmente dispomos, apesar de ter sofrido correções e manipulações, não deve ser considerado como tardio ou uma falsificação.

Mas, para além das chamadas críticas interna e externa, outros problemas foram levantados: como a proibição da leitura de outras hagiografias além da LM e a destruição das já existentes, em 1266, afetou a transmissão das obras? Como esta interdição marcou os textos que foram produzidos após esta data? Por que a $1 \mathrm{Cel}$, que foi escrita a pedido do papa e alçada a texto oficial em 1229, foi posteriormente proibida? O que aconteceu com o material que foi enviado ao Ministro Geral após o capítulo de 1244? Todas as informações foram usadas por Celano ou houve uma seleção de dados? Se houve uma seleção, que critérios foram usados? Qual a relação de dependência entre estas hagiografias? Que obras transmitem o "verdadeiro" Francisco, as que foram consideradas oficiais ou as que se ligam a um dos primeiros companheiros do Poverello, como os frades Egídio, Leão, Rufino e Ângelo?

Grande parte destas questóes foi suscitada a partir dos estudos de Paul Sabatier, desenvolvidos no fim do século XIX, dando origem ao que os críticos chamam de "Questão Franciscana".

Sabatier era protestante e inovou as pesquisas sobre as fontes franciscanas ao valorizar os escritos de Francisco acima dos demais textos; aplicar de forma rigorosa as técnicas das críticas interna e externa às fontes, 
e ao considerar Francisco separado da institucionalização da Ordem, que teria sido obra do papado.

Uma de suas contribuições mais relevantes foi a descoberta e publicação, em 1898, de um manuscrito, que denominou como a Legenda antiqüissima. Para o autor esta obra era a mais antiga e fiel hagiografia sobre Francisco, redigida antes de $1 \mathrm{Cel}$ e de autoria de Frei Leão. A partir deste texto, Sabatier elaborou a tese de que os textos hagiográficos apresentavam dois Franciscos: um mais próximo ao histórico e outro deturpado pelas autoridades eclesiásticas.

A partir das reflexões deste estudioso, houve uma grande renovação dos estudos franciscanos e muitas investigaçôes foram suscitadas por autores como Raoul Manselli, Theophile Desbonnets, Jacques Dalarun, Grado Merlo, Giovanni Miccoli e Chiara Frugoni.

Ainda que nem todas as questóes acima tenham recebido respostas, há algum consenso entre os estudiosos. Em primeiro lugar, que é impossível construir uma biografia "clássica” sobre Francisco. Como destaca Dalarun, "La complejidad filológica de las leyendas es hija de la misma polisemia de la experiencia real de Francisco" ${ }^{34}$ Em segundo, que se faz necessário pensar a figura do Poverello à luz de outros textos além dos seus próprios escritos e os hagiográficos, como as crônicas e as regras, a fim de compreender as ações do fundador no decorrer da expansão do movimento. Estas perspectivas são contrárias às idéias de Sabatier e rompem com uma visão uníssona sobre a trajetória de Francisco. O fundador, com o decorrer do tempo e face às novas demandas, pode ter respondido de forma diversa, com suas ações e ensinos, aos problemas. E, em terceiro e último, há que estudar as imagens feitas sobre Francisco, pois podem conservar aspectos da vida do santo que foram propagados à margem dos textos ou que neles foram censurados.

Neste último caso, quero destacar duas contribuiçôes. A de Chiara Frugoni, que identificou, em duas pinturas de Giotto, formas diferentes de apresentar o recebimento dos estigmas por Francisco. Em um quadro que se

${ }^{34}$ DALARUN, 1988, p. 18. 
encontra no Louvre, proveniente da Igreja de S. Francisco de Pisa, ${ }^{35}$ os raios saem do serafim e chegam, sem cruzar, até Francisco. Já no Fresco Bardi, da Igreja de Santa Cruz de Florença, ${ }^{36}$ os raios se cruzam para que os que saem das mãos e pés do serafim cheguem exatamente nas mãos e pés correspondentes de Francisco. A primeira representação permite concluir que o Poverello é um reflexo de Cristo, a segunda, que ele se identifica com o Cristo.

A segunda é da professora da UFES, Maria Cristina Correia Leandro Pereira. ${ }^{37} \mathrm{O}$ sonho que Inocêncio III teve, antes de encontrar com Francisco, no qual um homem pequeno segura a Igreja de Latrão, também é pintado de forma diversa por Giotto. No afresco da Basílica de Assis, Francisco sustenta a Igreja estando dentro dela. ${ }^{38}$ Já na pintura que está no Museu do Louvre, proveniente da Igreja de S. Francisco de Pisa, ${ }^{39}$ Latrão é apoiada por Francisco com os pés fora da Igreja. ${ }^{40}$ Como no caso anterior, este simples detalhe pode representar duas distintas relaçóes de Francisco com a Igreja. Na primeira, o Santo mantém a instituição participando dela. Na segunda, Francisco, um leigo, vem de fora para apoiar a Igreja.

35 Imagem disponível em http://www.italica.rai.it/argomenti/storia_arte/ giotto/galleria/2.jpg. Acesso em 09/02/2010.

${ }^{36}$ Imagem disponível em http://www.shafe.co.uk/art/Florence-_S-_Croce_Bardi_Chapel-_Giotto.asp. Acesso em 09/02/2010.

37 As considerações da professora estão apresentadas no texto Dos detalhes nas imagens: dois afrescos do ciclo franciscano na Basílica superior de Assis, a ser publicado nas Atas do VIII Encontro Internacional de Estudos Medievais, realizado na UFES, em agosto de 2009.

38 Imagem disponível em http://www.umbrarte.com/list/240101.htm. Acesso em 09/02/2010.

${ }^{39}$ Esta imagem compõe o retábulo Stigmate di san Francesco, citado na nota 34. Ver http://upload.wikimedia.org/wikipedia/commons/9/9b/ Giotto_di_Bondone_002.jpg. Acesso em 09/02/2010.

${ }^{40}$ Imagem disponível em http://upload.wikimedia.org/wikipedia/commons/ 4/43/Legend_of_St._Francis_the_dream_by_Giotto.jpg. Acesso em 09/ 02/2010. 


\section{Considerações finais}

As relações entre contexto, personagens, texto, autoria e recepção são dinâmicas. Os contextos afetam e são afetados de formas diferentes pelos personagens históricos e pelos textos, que são produzidos, recebidos e perpetuados de formas complexas. Assim, não é possível reduzir um personagem ou um texto a uma única compreensão, vista como completa e fiel ao real.

Francisco de Assis e o franciscanismo nasceram em um momento de profundas transformações na Península Itálica. Foram afetados por este contexto, mas também intervieram nele, ao proclamarem uma espiritualidade pautada na pobreza, na pregação, e na assistência. Com a expansão e o crescimento da Ordem, estes ideais foram sofrendo releituras, a fim de responder aos conflitos internos, às críticas da sociedade e às demandas da Igreja.

Durante o primeiro século franciscano foi elaborada uma ampla produção literária sobre a qual ainda há muitos debates. Este conjunto de textos, a despeito dos problemas críticos que os envolvem, são, contudo, um rico material para o estudo do primeiro século da nova instituição religiosa, sobretudo pela polissemia que representam. Ainda há muito a ser explorado, partindo de outras premissas teórico-metodológicas e ampliando as análises para abarcar também as imagens, a fim de construirmos saberes sobre a trajetória de Francisco e dos frades do século XIII. Deixamos aos leitores o convite para conhecer e explorar tais escritos. 


\section{Bibliografia}

ALBERZONI, Maria Pia et al. Francisco de Asis y el primer siglo de historia franciscana. Oñati: Editorial Franciscana Aránzazu, 1999.

BARRIOS GARCÍA, Ángel. Sobre el poblamiento medieval de la Extremadura Castellana. Crítica de una descripción estática e incompleta. Stvdia Histórica. Historia Medieval, Salamanca, v. 2, p. 201 -206, 1984.

BOLTON, Brenda. A Reforma na Idade Média. Lisboa: Edições 70, 1983.

CAUNEDO DEL POTRO, Betsabé. La formación y educación del mercader. In: IGLESIA DUARTE, J. I. de la. (Coord.). El comercio en la Edad Media. Semana de Estudios Medievales, 16, Nájera e Tricio, de 1 a 5 de agosto de 2005. Atas... Logroño: IER, 2006. p. 417-454.

CARDINI, F. A Itália entre os séculos XI e XIII. In: MONGELLI, L. M. (Org.). Mudanças e rumos: o Ocidente medieval (séculos XI - XIII). Cotia: Íbis, 1997. p. 83 - 108.

DALARUN, Jacques. La malaventura de Francisco de Asís. Oñati: Editorial Franciscana Aránzazu, 1998.

DALARUN, Jacques. Vers une Résolution de la question franciscaine. La Légende ombrienne de Thomas de Celano. Paris: Fayard, 2007.

DESBONNETS, T. Da intuição à instituição. Petrópolis: Cefepal, 1987.

FALBEL, Nachman. Heresias Medievais. São Paulo: Perspectiva, 1977.

FRANCO JÚNIOR, Hilário. A Idade Média. O Nascimento do Ocidente. São Paulo: Brasiliense, 2001.

FRUGONI, Chiara. Francesco e l'Invenzione delle Stimmate. Una storia per parelo e immagini fino a Fonaventura e Giotto. Torino: Einaudi, 1993.

GENICOT, L. Europa en el siglo XIII. Barcelona: Labor, 1976.

HOUAIS eletrônico 1.0. Rio de Janeiro: Objetiva, 2009.

IGLESIA DUARTE, J. I. de la. (Coord.). Espiritualidad y Franciscanismo. Semana de Estudios Medievales, 6, Nájera, 31 de julho a 4 de agosto de 1995. Atas... Logroño: IER, 1996. 
LE GOFF, Jacques. As raizes medievais da Europa. Petrópolis: Vozes, 2007.

LE GOFF, Jacques. (Dir). O Homem Medieval. Lisboa: Presença, 1990.

LE GOFF, Jacques. São Francisco de Assis. Rio de Janeiro: Record, 2001.

LE GOFF, Jacques; SCHMITT, Jean-Claude (Dir.). Dicionário Temático do Ocidente Medieval. Bauru, SP: EDUSC, 2002. 2V.

McEVEDY, Colin; JONES, Richard. Atlas of World Population History. Harmondsworth: Penguin Books, 1978.

MANSELLI, Raoul. Vida de San Francisco de Assis. Oñati: Editorial Franciscana Aránzazu, 1997.

MERLO, G. G. Em nome de São Francisco. Petrópolis: Vozes/FFB, 2005.

MICCOLI, Giovanni. Francisco de Assis. Petrópolis: FFB, 2004.

MOORE, R. I. La formación de una sociedad represora. Poder y disidencia en la Europa occidental, 950-1250. Barcelona: Crítica, 1989.

PAUL, J. História Intelectual do Occidente Medieval. Madrid: Cátedra, 2003.

SABATIER, Paul. Vida de São Francisco de Assis. Bragança Paulista: Editora Universitária São Francisco/Instituto Franciscano de Antropologia, 2006.

SCHMUCKI, O. "Soy ignorante e idiota” (CtaO 39). El grado de formación escolar de san Francisco de Asís. Selecciones de Franciscanismo, v. XI, n. 31, p. 89-106, 1982.

TEIXEIRA, C. M. et al. (Tradutor). Fontes Franciscanas e Clarianas. Petrópolis: Vozes, 2004.

VAUCHEZ, André. A Espiritualidade na Idade Média Ocidental: séculos VIII a XIII. Rio de Janeiro: Jorge Zahar, 1995.

VÉRDON, Jean. Sombras y luces de la Edad Media. Buenos Aires: El Ateneo, 2006.

VERGER, Jacques. Homens e Saber na Idade Média. Bauru: EDUSC, 1999. ZUNTHOR, Paul. La medida Del mundo. Madri: Cátedra, 1994. 


\section{Resumo}

O movimento franciscano surgiu no século XIII, na cidade de Assis, Península Itálica, a partir da conversão de Francisco, tendo como principais ideais a pobreza, a pregação e a vida comunitária. Filho de mercadores, apesar de ter estudado, Francisco não era versado em latim, nem nas disciplinas das nascentes universidades, contudo, sua vida e obra foram perpetuadas em textos de diversos letrados. Este artigo apresenta e traça reflexões sobre a produção literária atribuída ao Poverello, bem como sobre os escritos hagiográficos do chamado primeiro século franciscano, elaborados pelos irmãos menores, destacando as particularidades formais e os conflitos entre as tradiçóes textuais.

\section{Resumen}

El movimiento franciscano surgió en el siglo XIII, en la ciudad de Assis, Península Itálica, desde la conversión de Francisco, teniendo como principales ideales la pobreza, la predicación y la vida comunitaria. Hijo de mercader, a pesar de haber estudiado, Francisco no era versado en latín ni en las disciplinas de las nacientes universidades, sin embargo, su vida y obra fueron perpetuadas en textos de diversos letrados. Este artículo presenta y plantea reflexiones sobre la producción literaria atribuida al Poverello, bien como sobre los escritos hagiográficos del llamado primer siglo franciscano, elaborados por los hermanos menores, destacando las particularidades formales y los conflictos entre las tradiciones textuales. 